\title{
Article
}

\section{Efektivitas Program Keluarga Harapan Dalam Meningkatkan Kesejahterahan Masyarakat Desa Pulau Lebar Kecamatan Tabit Barat Kabupaten Merangin}

\author{
Mulia Jaya ${ }^{1 *}$, Domri²
}

This article is an open access article distributed under the terms and conditions of the Creative Commons Attribution-ShareAlike 4.0 International (CC BY SA ) License (https://creativecommo ns.org/licenses/bysa $/ 4.0 /)$.

\section{Jurnal Politik dan} Pemerintahan Daerah ISSN 2686-2271

Fakultas Ilmu Sosial dan Ilmu Politik, Universitas Muara Bungo Jl. Diponegoro No. 27, Muara Bungo-Jambi, (0747) 323310

\author{
${ }^{1}$ Program Studi Ilmu Pemerintahan Fakultas Ilmu Sosial Dan Ilmu Politik, Universitas \\ Muara Bungo, Kabupaten Bungo, Provinsi Jambi \\ 2 Program Studi Ilmu Pemerintahan Fakultas Ilmu Sosial Dan Ilmu Politik, Universitas \\ Muara Bungo, Kabupaten Bungo, Provinsi Jambi \\ * Correspondence Author: lakes_krs@yahoo.co.id
}

Abstract: The purpose of this study was to determine the effectiveness of the PKH program in improving the welfare of the people of Pulau Lebar Village, Tabir Barat Subdistrict and to determine the efforts of the Pulau Lebar Village government, Tabir Barat District, in overcoming obstacles to the $\mathrm{PKH}$ program in improving community welfare. The method used in this study is a qualitative research method with a descriptive study. The method used in this research is a qualitative research method with a descriptive study. The informant selection technique used by the researcher in this research is to use the purposive sampling method (the technique of determining the sample with certain considerations). The results of this study indicate that the PKH Program is effective in improving the welfare of the people of Pulau Lebar Village, Tabir Barat District, where PKH is helping to reduce poverty by improving the quality of human resources in the very poor community. In the short term, this assistance helps reduce the expenditure burden on RTSM, while in the long term, by requiring recipient families to send their children to school, immunize children under five, check the womb for pregnant women, and improve nutrition, it is hoped that it will break the intergenerational poverty chain. There are obstacles to the $\mathrm{PKH}$ program in improving the welfare of the people of Pulau Lebar Village, Tabir Barat District, including: low community participation, technical obstacles in the process of collecting data on $\mathrm{PKH}$ program recipients, technical obstacles in assisting the $\mathrm{PKH}$ program, as well as technical obstacles in the distribution/distribution and use of PKH program funds. . The efforts of the Pulau Lebar Village Government, Tabir Barat Sub-district in overcoming obstacles to the PKH program in improving community welfare include; increasing socialization, updating data on $\mathrm{PKH}$ recipients, certainty of payment schedules, suspension or cancellation of participants

Keywords: Effectiveness, Family Hope Program, Welfare

Abstrak: Tujuan dilakukan penelitian ini adalah untuk mengetahui efektivitas program PKH dalam meningkatkan kesejahteraan masyarakat Desa Pulau Lebar Kecamatan Tabir Barat dan untuk mengetahui upaya pemerintah Desa Pulau Lebar Kecamatan Tabir Barat dalam mengatasi hambatan pada program PKH dalam meningkatkan kesejahteraan masyarakat. Metode yang digunakan dalam penelitian ini penelitian ini adalah metode penelitian kualitatif yang bersifat dengan studi deskriptif. Metode yang digunakan dalam penelitian ini penelitian ini adalah metode penelitian kualitatif yang bersifat dengan studi deskriptif. Teknik pemilihan informan yang digunakan oleh peneliti dalam penelitian ini adalah dengan menggunakan metode purposive sampling 
(teknik penentuan sampel dengan pertimbangan tertentu). Hasil penelitian ini menunjukkan bahwa Program PKH efektif dalam dalam meningkatkan kesejahteraan masyarakat Desa Pulau Lebar Kecamatan Tabir Barat, dimana PKH adalah membantu mengurangi kemiskinan dengan cara meningkatkan kualitas sumber daya manusia pada kelompok masyarakat sangat miskin. Dalam jangka pendek, bantuan ini membantu mengurangi beban pengeluaran RTSM, sedangkan untuk jangka panjang, dengan mensyaratkan keluarga penerima untuk menyekolahkan anaknya, melakukan imunisasi balita, memeriksakan kandungan bagi ibu hamil, dan perbaikan gizi, diharapkan akan memutus rantai kemiskinan antar generasi. Terdapat hambatan program PKH dalam meningkatkan kesejahteraan masyarakat Desa Pulau Lebar Kecamatan Tabir Barat, diantaranya adalah: rendahnya partisipasi masyarakat, kendala teknis dalam proses pendataan penerima program $\mathrm{PKH}$, kendala teknis dalam pendampingan program $\mathrm{PKH}$, serta kendala teknis dalam penyaluran/pendistribusian dan penggunaan dana program PKH. Upaya Pemerintah Desa Pulau Lebar Kecamatan Tabir Barat dalam mengatasi hambatan pada program PKH dalam meningkatkan kesejahteraan masyarakat diantaranya; meningkatkan sosialisasi, pemutakhiran data penerima $\mathrm{PKH}$, kepastian jadwal pembayaran, penangguhan atau pembatalan peserta

Kata Kunci: Efektivitas, Program Keluarga Harapan, Kesejahteraan

\section{Pendahuluan}

Dalam rangka percepatan penanggulangan kemiskinan sekaligus pengembangan kebijakan dibidang perlindungan sosial, tahun 2007 Pemerintah Indonesia telah meluncurkan Program Keluarga Harapan (PKH). Program bantuan tunai bersyarat atau disebut dengan Conditional Cash Trasfers (CCT), telah dilaksanakan dibeberapa negara dan cukup berhasil dalam menanggulangi kemiskinan yang dihadapi negara-negara tersebut. Program Keluarga Harapan (PKH) yang sudah berlangsung selama ini dalam rangka membantu rumah tangga sangat miskin mempertahankan daya beli pada saat pemerintah melakukan penyusuian harga BBM. Program Keluarga Harapan (PKH) lebih dimaksudkan sebagai upaya membangun sistem perlindungan sosial pada masyarakat miskin dalam ranggka mempertahankan dan meningkatkan kesejahteraan sosial penduduk miskin sekaligus upaya memotong rantai kemiskinan yang terjadi selama ini. PKH bertujuan untuk mengurangi kemiskinan dalam jangka pendek sekaligus meningkatkan kesejahterahan masyarakat dengan menambah kesempatan untuk memperoleh pendidikan dan fasilitas kesehatan (Lee \& Hwang, 2016).

Program Keluarga Harapan merupakan bantuan dan perlindungan sosial yang termasuk dalam kluster pertama strategi penanggulangan kemiskinan di Indonesia. Program ini tidak memerlukan keterlibatan masyarakat secara langsung meskipun dalam pelaksanaanya terdapat pendampingan untuk kegiatan peningkatan masyarakat, namun pada dasarnya program ini bersifat top-down yang merupakan program yang ditentukan langsung oleh pemerintah dan tidak melibatkan masyarakat (Suleman \& Resnawaty, 2017). Program ini merupakan bantuan bersyarat dan disesuaikan dengan persyaratan pendidikan dan kesehatan. Kesembungan dari program ini akan berkontribusi dalam mempercepat pencapaian tujuan pembangunan melenium (Millennium Developmen Goals atau MDGs) (Direktorat Jaminan Sosial \& RI, 2012). Setidaknya ada 5 komponem tujuan MDGs yang didukung melalui PKH, yaitu penanggulangan kemiskinan ekstrim dan kelaparan, pencapain pendidikan dasar untuk semua, kesetaraan gender dan pemberdayaan perempuan, pengurangan angka kematian anak, dan peningkatan kesehatan ibu. 
Dengan PKH diharapkan Perserta PKH (selajutnya disebut Rumah Tangga/Keluarga Sangat Miskin (RTSM/KSM) memiliki akses yang sangat baik untuk memanfaatkan pelayanan sosial dasar, yaitu kesehatan, pendidikan, pangan dan gizi, termasuk menghilangkan kesenjangan sosial, ketidak berdayaan dan keterasingan sosial yang selama ini melekat pada diri masyarakat miskin. Peserta PKH memiliki berbagai kewajiban yang harus dipenuhi khususnya kewajiban yang dibidang kesehatan dan pendidikan. Kewajiban dibidang kesehatan berkaitan dengan pemeriksaan kandungan bagi ibu hamil, pemeriksaan kesehatan, pemberian asupan gizi dan imunisasi anak balita. Di bidang pendidikan kewajiban peserta PKH terkait dengan menyekolahkan anak kesekolah dasar dan lanjutan (SD s.d SLTP/SMP).

PKH akan memberikan manfaat jangka pendek dan jangka panjang. Untuk jangka pendek, PKH akan memberikan income effect kepada RTSM/KSM melalui pengurangan beban pengeluaran rumah tangga. Untuk jangka panjang, program ini diharapkan mampu memutus rantai kemiskinan antar generasi melalui peningkatan kualitas kesehatan/nutrisi, pendidikan dan kapasitas pendapatan anak dimasa depan (serta memberikan kepastian kepada si anak akan masa depannya. Secara faktual dan menurut teori yang ada, tingkat kemiskinan suatu rumah tangga secara umum terkait dengan tingkat kesehatan dan pendidikan. Rendahnya penghasilan keluarga sangat miskin menyebabkan keluarga tersebut tidak mampu memenuhi kebutuhan kesehatan dan pendidikan, untuk tingkat minimal sekalipun.

Masih banyaknya RTSM/KSM yang belum dapat memenuhi kebutuhan dasar pendidikan dan kesehatan disebabkan oleh akar permasalahan yang tterjadi baik pada sisi RTSM/KSM maupun sisi pelayanan. Pada sisi permintaan, alasan tersebar untuk tidak melanjutkan sekolah karena tidak adanya biaya, berkerja untuk mencari nafkan, merasa pendidikannya sudah cukup, dan alasan lainnya. Demikian juga halnya untuk kesehatan, RTSM/KSM tidak mampu membiayai pemeliharaan atau perawatan kesehatan bagi anggota keluarga akibat rendahnya tinggkat pendapatan. Sementara itu permasalahan pada sisi pelayanan yang menyebabkan rendahnya akses RTSM/KSM terhadap pendidikan dan kesehatan antara lain adalah belum tersedianya pelayanan kesehatan dan pendidikan yang tejangkau oleh RTSM/KSM.

Biaya pelayan yang tidak tejangkau oleh RTSM/KSM serta jarak antar tempat tinggal dan lokasi pelayan yang relatif jauh mrupakan tantangan utama bagi penyedia pelayan pendidikan dan kesehatan dari sisi kebijakan sosial, PKH merupakan cikal bakal pengembangan sistem perlindungan sosial, khususnya bagi keluarga miskin. PKH yang mewajibkan RTSM/KSM memeriksakan kesehatan ibu hamil dan memberikan imunisasi dan pemantauan tumbuk kembang anak termasuk menyekolahkan anak-anak, akan membawa perubahan perilaku RTSM/KSM terhadap pentingnya kesehatan dan pendidikan. Perubahan perilaku tersebut diharapkan juga berdampak pada berkurangnya anak usia sekolah RTSM/KSM yang berkerja. Sebaliknya, hal ini menjadi tantangan utama pemerintah, baik pusat maupun daerah, untuk meningkatkan pelayanan pendidikan dan kesehatan bagi keluarga miskin, dimanapun mereka berada. Salah satu tujuan akhir dari PKH adalah meningkatkan partisipasi sekolah anak khususnya SD dan SMP (Direktorat Jaminan Sosial \& RI, 2012).

Menurut BPS masih terdapat banyak anak usia sekolah yang tidak berada dalam sistem sekolah. Untuk meningkatkan tingkat pasrtisipasi anak dalam sekolah maka keikutsertaan mereka yang berada diluar sistem sekolah harus di tingkatkan. Sebagian besar dari mereka yang tidak berada dalam sistem sekolah biasanya berkerja untuk membantu kehidupan keluarga. PKH merupakan salah satu program penangulangan kemiskinan yang melibatkan beberapa sektor yang 
dalamnya memerlukan kontribusi dan komitmen lembaga/istansi terkait yang meliputi: Kementerian Kesehatan, Kementerian Pendidikan dan Kebudayaan, Kementerian Agama, BPS, dan PT Pos Indonesia dan lembaga Keuangan perbankan dalam penyaluran bantuan bagi peserta PKH. Peran Pemerintahan Derah (pemda) dalam memastikan kesediaan sarana dan prasarana fasilitas kesehatan pendidikan sangat dibutukkan untuk kelancaran pelaksanaan PKH ini sesuai komitmen yang sudah ditandatangani oleh masing-masing kepala daerah.

Berdasarkan hasil penelitian Lidiana tentang pengaruh dan efektifitas bantuan Program Keluarga Harapan (PKH) terhadap partisipasi pendidikan di Kecamatan Muara Tiga Kabupaten Pidie, diketahui bahwa rata-rata tingkat efektifitas pemberian bantuan PKH dari tahun 2008-2013 mencapai 95,58 persen. Bantuan PKH mampu menjelaskan atau mempengaruhi partisipasi pendidikan anak - anak RTSM di Kecamatan Muara Tiga Kabupaten Pidie mencapai 96,8 persen dan sisanya sebesar 3,2 persen di pengaruhi oleh variabel lainnya diluar model penelitian ini (Lidiana, 2014).

Puslitbangkesos Kementerian Sosial telah melakukan penelitian pada tujuh provinsi di Indonesia tentang dampak pada rumah tangga sangat miskin. Penelitian yang dibukukan ini bertujuan untuk mengetahui dampak pelaksanaan Program Keluarga Harapan (PKH) di tujuh provinsi serta merumuskan peluang pengembangan $\mathrm{PKH}$ di Indonesia. Hasil penelitian menunjukkan bahwa secara umum, kondisi RTSM pasca PKH lebih baik daripada kondisinya sebelum PKH, meskipun di beberapa provinsi justru mengalami penurunan status sosial ekonomi dan penurunan ketangguhan (resiliensi) Rumah Tangga Sangat Miskin (RTSM). (Nainggolan et al., 2012)

Hasil penelitian Antriya Eka Suwinta tentang implementasi Program Keluarga Harapan (PKH) di Desa Maron Kecamatan Kademangan Kabupaten Blitar menunjukkan bahwa implementasi PKH di Desa Maron Kecamatan Kademangan Kabupaten Blitar kurang berhasil. Hal ini dikarenakan walaupun serangkaian tahapan yang berjalan dengan lancar, sumberdaya yang dimiliki meliputi staf, kewenangan, informasi dan fasilitas maupun kemampuan pelaksana (disposisi) PKH di Desa Maron juga telah memberikan kontribusi pada pelaksanaan PKH dan para pelaksana di Desa Maron juga telah menjalankan tugas sesuai dengan Standard Operational Procedures (SOP's) serta melakukan pembagian tata kerjanya dengan baik. (Kajian Kebijakan Publik, 2016)

Berdasarkan observasi awal peneliti di Desa Pulau Lebar Kecamatan Tabir Barat Kabupaten Merangin diketahui bahwa program PKH telah mampu mendorong masyarakat yang berada pada kategori RTSM/KSM untuk meningkatkan kesejahteraan mereka melalui perubahan pola hidup dan perilaku yang menyangkut pendidikan dan perbaikan kesehatan, dengan pendidikan yang memadai diharapkan keluarga sangat miskin mampu keluar dari jeratan kemiskinan serta dengan kondisi kesehatan yang baik RTSM/KSM dapat bekerja dan menghasilkan pendapatan yang memadai sehingga pada akhirnya mampu meningkatkan kesejahteraan mereka. Dengan jumlah penerima manfaat sebanyak 42 orang, berikut rinciannya:

Tabel 1. Daftar Penerima Manfaat Program PKH Desa Desa Pulau Lebar Kecamatan Tabir Barat Tahun 2017

\begin{tabular}{l|l|l|l} 
No & Rincian & Jumlah & Keterangan \\
1 & Ibu Hamil & 6 orang & \\
2 & Balita & 8 orang & \\
3 & Siswa Sekolah (SD/SMP) & 28 orang & \\
Total & 42 orang &
\end{tabular}

Sumber : Pendamping PKH Kecamatan Tabir Barat, 2017 
Dalam pelaksanaan program PKH di Desa Pulau Lebar Kecamatan Tabir Barat Kabupaten Merangin, peneliti juga menemukan beberapa permasalahan yang menjadi kendala dalam upaya pemerintah untuk meningkatkan kesejahteraan masyarakat, permasalahan yang sangat krusial yaitu masih ada penerima program PKH yang tidak tepat sasaran, dimana penerima program PKH diberikan kepada orang yang mampu dan ada juga penerima program PKH yang merupakan usia lanjut, padahal tujuan utama PKH adalah membantu mengurangi kemiskinan dengan cara meningkatkan kualitas sumber daya manusia pada kelompok masyarakat sangat miskin. Dalam jangka pendek, bantuan ini membantu mengurangi beban pengeluaran RTSM, sedangkan untuk jangka panjang, dengan mensyaratkan keluarga penerima untuk menyekolahkan anaknya, melakukan imunisasi balita, memeriksakan kandungan bagi ibu hamil, dan perbaikan gizi, diharapkan akan memutus rantai kemiskinan antar generasi.

Selain itu peneliti juga mendapatkan keluhan dari penerima program PKH mengenai proses pencairan yang mengharuskan melalui kantor POS, berhubungan Kantor POS hanya ada di Pasar Rantau Panjang Kecamatan Tabir, maka penerima program PKH diharuskan mengambil dana tersebut di Kantor POS Pasar Rantau Panjang yang jarak tempuhnya mencapai $48 \mathrm{~km}$ dengan menghabiskan waktu perjalanan 2 jam menggunakan kendaraan umum, dikarenakan kondisi jalan yang kurang baik. Terkadang mereka harus menginap dikarenakan mengantri terlalu lama sehingga tidak cukup waktu untuk pulang.

Permasalahan lainnya yang peneliti temukan adalah kurangnya peran pendamping PKH dalam meningkatkan kesejahteraan masyarakat di Desa Pulau Lebar Kecamatan Tabir, hal ini terlihat dari kurangnya pendampingan yang diberikan, pendamping hanya terlihat pada saat pendataan dan pemberian informasi ketika dana cair, namun kurang dalam pendampingan rutin. Padahal setiap RTSM yang menerima dana bantuan didampingi oleh pendamping dalam pengalokasian dana yang telah didapatkan agar tepat pada sasaran yaitu untuk pendidikan dan kesehatan. Peran pendamping PKH menjadi sangat penting karena mayoritas Penerima dana PKH merupakan RTSM yang memiliki tingkat pendidikan yang rendah sehingga membutuhkan fasilitas pendampingan. Proses pendampingan yang dilakukan oleh pendamping PKH merupakan agenda rutin yang harus dilakukan sebagai upaya mengarahkan RTSM agar tepat dalam penggunaan dana bantuan tersebut.

Berdasarkan permasalahan yang diungkapkan di atas, maka peneliti tertarik untuk melakukan kajian lebih lanjut dalam bentuk karya ilmiah yang peneliti tuangkan pada proposal yang berjudul "EFEKTIVITAS PROGRAM KELUARGA HARAPAN DALAM MENINGKATKAN KESEJAHTERAAN MASYARAKAT DESA PULAU LEBAR KECAMATAN TABIR BARAT".

\section{Pembahasan}

Efektivitas program PKH dalam meningkatkan kesejahteraan masyarakat Desa Pulau Lebar Kecamatan Tabir Barat

Kemiskinan merupakan kondisi saat sesorang atau sekelompok orang tak mampu memenuhi hak-hak dasarnya untuk mempertahankan dan mengembangkan kehidupan yang bermartabat. Kemiskinan yang diterapkan dibanyak negara termasuk Indonesia adalah kemampuan memenuhi kebutuhan dasar. Kemiskinan ditandai dengan rendahnya kualitas hidup penduduk, pendidikan, kesehatan dan gizi Dalam rangka percepatan penanggulangan kemiskinan sekaligus pengembangan kebijakan di bidang perlindungan sosial, dimulai pada tahun 2007 pemerintah melaksanakan Program Keluarga Harapan (PKH). PKH juga sebagai sarana untuk mengembangkan sistem jaminan sosial bagi 
masyarakat sangat miskin. Program serupa ini di negara lain dikenal dengan istilah Conditional Cash Transfers (CCT) atau Bantuan Tunai Bersyarat.

Bantuan yang disalurkan kepada peserta PKH bersumber dari APBN, dan untuk kelancaran pelaksanaan di Kabupaten Kota diperlukan dukungan APBD untuk kelancaran kegiatan dan Pelaksanaan PKH. Pelaksanaan program keluarga harapan (PKH) hingga tahun 2015 diharapkan dapat menjadi sebuah solusi dalam upaya memutus rantai kemiskinan bagi RTSM dimana kepesertaan PKH tidak hanya dapat memberikan manfaat bagi masyarakat penerima PKH saja, tetapi perubahan pola hidup dan perilaku yang menyangkut pendidikan dan perbaikan kesehatan dapat berdampak luas kepada masyarakat di wilayah dilaksanakannya program PKH. Dalam pelaksanaannya peserta yang menerima dana PKH akan menerima bantuan selama maksimal enam tahun. kualitas hidupnya.

Faktor penting penunjang berjalannya program yaitu peran dari tim pendamping PKH. Dalam pelaksanaannya setiap RTSM yang menerima dana bantuan didampingi oleh pendamping dalam pengalokasian dana yang telah didapatkan agar tepat pada sasaran yaitu untuk pendidikan dan kesehatan. Peran pendamping PKH menjadi sangat penting karena mayoritas Penerima dana PKH merupakan RTSM yang memiliki tingkat pendidikan yang rendah sehingga membutuhkan fasilitas pendampingan. Proses pendampingan yang dilakukan oleh pendamping PKH merupakan agenda rutin yang harus dilakukan sebagai upaya mengarahkan RTSM agar tepat dalam penggunaan dana bantuan tersebut.

Pendampingan merupakan proses komunikasi yang dilakukan secara rutin antara pendamping dengan rumah tangga sangat miskin (RTSM) penerima dana PKH. Efektivitas komunikasi antara kedua aktor tersebut menjadi sangat penting untuk dilihat karena komunikasi yang efektif di antara kedua aktor tersebut memungkinkan terjadinya perubahan pada diri penerima dana tersebut yang mengarah kepada perubahan yang positif dalam hal pengetahuan, sikap serta tindakan terkait pendidikan dan kesehatan. Sasaran atau Penerima bantuan PKH adalah Rumah Tangga Sangat Miskin (RTSM) yang memiliki anggota keluarga yang terdiri dari anak usia 0-15 tahun dan/atau ibu hamil/nifas dan berada pada lokasi terpilih. Penerima bantuan adalah lbu atau wanita dewasa yang mengurus anak pada rumah tangga yang bersangkutan (jika tidak ada lbu maka: nenek, tante/bibi, atau kakak perempuan dapat menjadi penerima bantuan).

Jadi, pada kartu kepesertaan PKH pun akan tercantum nama ibu/wanita yang mengurus anak, bukan kepala rumah tangga. Untuk itu, orang yang harus dan berhak mengambil pembayaran adalah orang yang namanya tercantum di Kartu PKH. Calon Penerima terpilih harus menandatangani persetujuan bahwa selama mereka menerima bantuan, mereka akan: (1) Menyekolahkan anak 7-15 tahun serta anak usia 16-18 tahun namun belum selesai pendidikan dasar 9 tahun wajib belajar; (2) Membawa anak usia 0-6 tahun ke fasilitas kesehatan sesuai dengan prosedur kesehatan PKH bagi anak; dan (3) Untuk ibu hamil, harus memeriksakan kesehatan diri dan janinnya ke fasilitats kesehatan sesuai dengan prosedur kesehatan PKH bagi lbu Hamil. Dalam pengertian PKH jelas disebutkan bahwa komponen yang menjadi fokus utama adalah bidang kesehatan dan pendidikan (Pedoman Umum PKH: 2012).

Peraturan Menteri Sosial Nomor 1 Tahun 2018 tentang Program Keluarga Harapan Pasal 2 menjelaskan bahwa PKH bertujuan: untuk meningkatkan taraf hidup Keluarga Penerima Manfaat melalui akses layanan pendidikan, kesehatan, dan kesejahteraan sosial, mengurangi beban pengeluaran dan meningkatkan pendapatan keluarga miskin dan rentan, menciptakan perubahan perilaku dan kemandirian Keluarga Penerima Manfaat dalam mengakses layanan kesehatan dan pendidikan serta kesejahteraan sosial, mengurangi kemiskinan dan kesenjangan; 
dan mengenalkan manfaat produk dan jasa keuangan formal kepada Keluarga Penerima Manfaat.

Tujuan utama PKH Kesehatan adalah meningkatkan status kesehatan ibu dan anak di Indonesia, khususnya bagi kelompok masyarakat sangat miskin, melalui pemberian insentif untuk melakukan kunjungan kesehatan yang bersifat preventif (pencegahan, dan bukan pengobatan). Seluruh peserta PKH merupakan penerima jasa kesehatan gratis yang disediakan oleh program Askeskin dan program lain yang diperuntukkan bagi orang tidak mampu. Kartu PKH bisa digunakan sebagai alat identitas untuk memperoleh pelayanan tersebut. Komponen pendidikan dalam PKH dikembangkan untuk meningkatkan angka partisipasi pendidikan dasar wajib 9 tahun serta upaya mengurangi angka pekerja anak pada keluarga yang sangat miskin. Anak penerima PKH Pendidikan yang berusia 7-18 tahun dan belum menyelesaikan program pendidikan dasar 9 tahun harus mendaftarkan diri di sekolah formal atau non formal serta hadir sekurang-kurangnya $85 \%$ waktu tatap muka. Setiap anak peserta PKH berhak menerima bantuan selain PKH, baik itu program nasional maupun lokal. Bantuan PKH bukanlah pengganti programprogram lainnya karenanya tidak cukup membantu pengeluaran lainnya seperti seragam, buku dan sebagainya. PKH merupakan bantuan agar orang tua dapat melanjutkan pendidikan keseluruh dalam rangka untuk melanjutkan pendidikan anak.

Adapun Peraturan Presiden Republik Indonesia Nomor 15 Tahun 2010 Tentang Percepatan Penanggulangan Kemiskinan, kemiskinan yaitu:

1. Bahwa kemiskinan merupakan permasalahan bangsa yang mendesak dan mengeluarkan langkah-langkah penangan dan pendekatan yang sistematik, terpadu dan menyeluruh, dalam rangka mengurangi beban dan memenuhi hak dasar warga negara secara layak melalui pembangunan inklusif, berkeadilan dan berkelanjutan untuk mewujudkan kehidupan yang bermatabat.

2. Bahwa dalam upaya pencepatan penanggulangan kemiskinan perlu dilakukan langkah-langka koordinasi secara terpadu lintas pelaku dalam penyiapan perumusan dan penyelenggaraan kebijakan penanggulangan kemiskinan.

Sedangkan tujuan utama PKH adalah membantu mengurangi kemiskinan dengan cara meningkatkan kualitas sumber daya manusia pada kelompok masyarakat sangat miskin. Dalam jangka pendek, bantuan ini membantu mengurangi beban pengeluaran RTSM, sedangkan untuk jangka panjang, dengan mensyaratkan keluarga penerima untuk menyekolahkan anaknya, melakukan imunisasi balita, memeriksakan kandungan bagi ibu hamil, dan perbaikan gizi, diharapkan akan memutus rantai kemiskinan antar generasi.

Demikian dengan keadaan kehidupan masayarakat di Desa Pulau Lebar Kecamatan Tabir Barat Kabupaten Merangin. Dimana sangat memerlukan bantuan Program Keluarga Harapan untuk membantu dalam kehidupan sehari-hari, sehingga dapat mengurangi beban Rumah Tangga Sangat Miskin.

Dengan demikian terlihat bahwa 28 orang penerima manfaat merupakan keluarga yang memiliki anak usia sekolah, sedangkan 8 orang penerima program PKH merupakan anak balita, sisanya sebanyak 6 orang merupakan ibu hamil. Jumlah tersebut tidak menggambarkan kondisi masyarakat di Desa Pulau Lebar, Padahal masih ada masyarakat yang sangat membutuhkan bantuan tersebut. Batuan PKH seharusnya bisa membantu masyarakat yang sangat membutuhkan sehingga mereka benar-benar bisa tertolong dari kemiskinan. Sehingga anak-anak mereka bisa melanjutkan sekolah. 
Program Keluarga Harapan (PKH) adalah program yang memberikan bantuan tunai bersyarat kepada Rumah Kangga/Keluarga Sangat Miskin (RTSM/KSM) yang telah ditetapkan sebagai peserta PKH diwajibkan memenuhi persyaratan dan komitmen yang terkait dengan upaya peningkatan kualitas Sumber Daya Manusia (SDM), yaitu pendidikan dan kesehatan. Sasaran PKH adalah Rumah Tangga/Keluarga Sangat Miskin (RTSM/KSM). Peseta PKH adalah RTSM/KSM yang memenuhi satu atau beberapa kriteria yaitu memiliki ibu hamil/ibu menyusui/ibu nifas/anak balita. Anak usia 5-7 tahun yang belum masuk pendidikan dasar (anak pra sekolah), anak SD/MI (usia 7-12 tahun), anak SLTP/MTsN (usia 12-15 tahun) dan anak usia 15-18 tahun yang belum menyelesaikan pendidikan dasar.

1. Meningkatkan Kualitas Kesehatan Rumah Tangga Miskin/Keluarga Sangat Miskin (RTM/KSM).

Kesehatan bagi Rumah Tangga Miskin yang sudah ditetapkan menjadi peserta PKH dan memiliki kartu PKH diwajibkan memenuhi persyaratan kesehatan yang sudah ditetapkan dalam protokol pelayanan. Untuk mengetahui gambaran tentang Program Keluarga Harapan (PKH) telah berjalan dengan prosedurnya di Desa Pulau Lebar Kecamatan Tabir Barat Kabupaten Merangin dapat dilihat tingginya kesadaran masyarakat untuk memperoleh kesehatan dan peduli terhadap perilaku hidup sehat. Apa yang disampaikan oleh informan berkesesuaian dengan hasil pengamatan di Posyandu Desa Pulau Lebar dan Puskesmas Muara Kibul, dimana peneliti banyak menemukan ibuibu yang memeriksa kesehatan mereka dan anak mereka.

Pembangunan erat kaitannya dengan pemenuhan kebutuhan masyarakat agar tercipta sebuah kesejahteraan. Dalam mewujudkan sebuah kesejahteraan masyarakat, pemerintah harus juga memperhatikan masalah kemiskinan. Karena kemiskinan merupakan hal yang tidak dapat dilepaskan dari masalah pemenuhan kebutuhan hidup. Kesejahteraan masyarakat dapat diukur dengan kemampuan masyarakat memenuhi kebutuhan hidupnya. Rendahnya kualitas hidup penduduk miskin berakibat pada rendahnya tingkat pendidikan dan kesehatan sehingga dapat mempengaruhi produktivitas. Dengan kondisi seperti ini menyebabkan dapat meningkatkannya beban ketergantungan bagi masyarakat. Penduduk yang masih berada di bawah garis kemiskinan mencakup mereka yang berpendapatan rendah, tidak berpendapatan tetap atau tidak berpendapatan sama sekali. Dengan demikian maka pengentasan dan penanggulangan kemiskinan yang diupayakan berbagai pihak diharapkan dapat mengangkat taraf hidup masyarakat miskin.

Kartasasmita menyebutkan bahwa kebijakan penanggulangan kemiskinan dapat tertuang dalam tiga arah kebijakan. Pertama, kebijakan tidak langsung yang diarahkan pada penciptaan kondisi yang menjamin kelangsungan setiap upaya penanggulangan kemiskinan; kedua, kebijakan langsung yang ditujukan kepada golongan masyarakat berpenghasilan rendah; dan ketiga, kebijakan khusus yang dimaksudkan untuk mempersiapkan masyarakat miskin itu sendiri dan aparat yang bertanggungjawab langsung terhadap kelancaran program, dan sekaligus memacu dan memperluas upaya penanggulangan kemiskinan. Program-program yang dilaksanakan dalam upaya pengentasan kemiskinan selama ini belum mampu memberikan 
dampak besar sehingga sampai saat ini tujuan dari pembanguanan nasional terkait dengan masalah pemerataan dan peningkatan kesejahteraan masyarakat masih menjadi masalah yang berkepanjangan. Oleh karena itu dalam rangka penanggulangan kemiskinan berbasis rumah tangga, Pemerintah meluncurkan program khusus yang diberi nama Program Keluarga Harapan (PKH). Menurut Dirjen Bantuan dan Jaminan Sosial PKH dirancang untuk membantu penduduk miskin kluster terbawah berupa bantuan bersyarat

2. Meningkatkan Taraf Pendidikan Anak-Anak RTM/KSMI

Pendidikan dan kapasitas pendapatan anak dimasa depan (price effect anak keluarga miskin memberikan kepastian kepada sianak akan masa depannya (insurance effect). Untuk mengetahui gambaran tentang Program Keluarga Harapan (PKH) membantu pendidikan bagi anak-anak dalam rumah tangga miskin/keluarga sangat miskin (RTSM/KSM) di Desa Pulau Lebar Kecamatan Tabir Barat Kabupaten Merangin terlihat dari tingginya angka partisipasi sekolah anak usia sekolah di Desa Pulau Lebar Kecamatan Tabir Barat Kabupaten Merangin.

PKH ini telah memberikan kemudahan pada keluarga miskin untuk menyekolahkan anaknya, meskipun pada kenyataannya belum memberikan perubahan penghidupan kepada keluarga miskin tersebut. Sebagai salah satu contoh dalam upaya untuk menyekolahkan anak, keluarga miskin mampu untuk membayar biaya sekolah namun tidak mampu untuk memberikan uang jajan maupun menempuh jarak sekolah yang cukup jauh dari tempat tinggal.

Tujuan Program PKH adalah meningkatkan kualitas hidup Keluarga Sangat Miskin (KSM) dengan syarat mengakses layanan kesehatan dan pendidikan tertentu yang telah ditetapkan bagi Keluarga Sangat Miskin (KSM). Kesempatan yang diberikan berupa akses tersebut, diharapkan terjadi perubahan perilaku yang mendukung tercapainya kesejahteraan sosial. Dalam jangka pendek dana bantuan PKH diharapkan mampu mengurangi beban pengeluaran rumah tangga (dampak konsumsi langsung), dan dalam jangka panjang merupakan investasi generasi masa depan yang lebih baik melalui peningkatan kesehatan dan pendidikan (dampak pengembangan modal manusia). Artinya, PKH diharapkan sebagai program yang mampu memutus rantai kemiskinan antar generasi khususnya di Desa Pulau Lebar Kecamatan Tabir Barat.

Program pengentasan kemiskinan melalui Program PKH ini mengarah pada outcome atau hasil dari kegiatan pengentasan kemiskinan yang selama ini telah dilaksanakan dari output atau keluaran yang akan di dapatkan output dari pengentasan kemiskinan ini memang hasilnya tidak secara langsung melainkan memerlukan waktu jangka panjang. Outcome yang diharapkan dari program ini adalah perubahan pola pikir masyarakat (RTSM) tentang pentingnya pendidikan dan kesehatan anak-anak mereka yang nantinya akan mencapai kesejahtraan masyarakat yang terjadi dalam kegiatan Program Keluarga Harapan (PKH) di Desa Pulau Lebar Kecamatan Tabir Barat sesuai konsep Implementasi merupakan proses untuk memastikan terlaksananya suatu kebijakan dan tercapainya kebijakan tersebut

Menurut Howlett dan Ramesh (dalam Suharto) mengatakan bahwa, implementasi kebijakan sangat dipengaruhi oleh hakekat dan perumusan masalah kebijakan itu, keragaman masalah yang ditangani oleh pemerintah, ukuran kelompok-kelompok sasaran, dan tingkat perubahan perilaku yang diharapkan. Implementasi kebijakan menurut Howlett dan Ramesh sebagai "proses dimana 
program atau kebijakan itu dilaksanakan; hal ini menunjukkan perubahan rencana menjadi praktek". Hal senada juga diungkapkan oleh Mazmanian dan Sabitier yang berpendapat bahwa peran penting analis implementasi kebijaksanaan Negara ialah mengidentifikasikan variable-variabel yang mempengaruhi tercapainya tujuantujuan formal pada seluruh proses implementasi. Variabel-variabel yang dimaksud antara lain: (1) Mudah tidaknya masalah yang digarap dikendalikan; (2) Kemampuan keputusan kebijaksanaan untuk menstrukturkan secara tepat proses implementasinya; dan (3) Pengaruh langsung perbagai variable politik terhadap keseimbangan dukungan bagi tujuan yang termuat dalam keputusan kebijaksanaan tersebut.

\section{Hambatan Program PKH dalam Meningkatkan Kesejahteraan Masyarakat Desa Pulau Lebar Kecamatan Tabir Barat}

Program Keluarga Harapan merupakan program yang bersifat memberikan bantuan langsung tunai pada masyarakat, guna untuk meningkatkan kualitas hidup melalui akses pendidikan dan kesehatan. Berdasarkan sudut pandang kesejahteraan sosial dapat dipahami bahwa PKH memang belum tepat jika disebutkan sebagai sebuah program pengentasan kemiskinan. Dipandang sebagai program perlindungan sosial PKH ini dapat dikatakan tepat namun belum terukur efektifitas pelaksanaannya. Terlebih tidak adanya indicator yang mengukur apakah masyarakat miskin tersebut telah mengalami perubahan dan siap untuk menerima program pengentasan kemiskinan dengan model pemberdayaan. Dikhawatirkan jika tidak didukung dengan upaya-upaya lain maka penerima program ini jumlahnya akan semakin banyak, serta tingkat ketergantungan masyarakat terhadap bantuan menjadi sangat tinggi yang menunjukkan kegagalam program pemerintah dalam meningkatkan keberdayaan masyarakat.

Berdasarkan hasil wawancara dengan beberapa informan diketahui bahwa terdapat hambatan program PKH dalam meningkatkan kesejahteraan masyarakat Desa Pulau Lebar Kecamatan Tabir Barat, diantaranya adalah:

1. Rendahnya Partisipasi Masyarakat

Jika disebut sebagai program pengentasan kemiskinan, Program Keluarga Harapan (PKH) merupakan model yang tidak melibatkan partisipasi masyarakat secara. Meskipun terdapat pendamping dan beberapa kegiatan peningkatan kapasitas masyarakat, Program ini bersifat top down, di mana program dilakukan langsung ditentukan oleh pemerintah dan masyarakat tidak dilibatkan sesuai dengan kapasitas yang mereka miliki. Padahal sebenarnya seberapapun miskinnya kondisi masyarakat tersebut, mereka memiliki kapasitas yang mampu dikembangkan. Sehingga selayaknya masyarakat tidak dipandang berada pada kondisi "gigi nol" atau tidak memiliki potensi apapun. Pengetahuan dan sosialisasi Program PKH yang dilakukan oleh Petugas PKH Kecamatan Tabir Barat Kabupaten M, terdapat kendala teknis yang menyebabkan sosialisasi tidak maksimal sehingga banyak masyarakat yang belum mengetahui Program PKH. Sosialiasi tidak menjangkau kepada Tokoh Masyarakat, Pejabat Kecamatan dan Kepala Dusun, sehingga pengetahuan mereka sangat minim tentang PKH. Kendalanya diantaranya, keterbatasan dalam mengumpulkan masyarakat dan stakeholders untuk dilakukan sosialisasi oleh petugas PKH di Kecamatan Tabir Barat, dikarenakan jarak tempat tinggal petugas yang jauh dari lokasi pendampingan menyebabkan sulit melakukan pertemuan dengan masyarakat dan stakeholders.

Kemudian, ketersediaan anggaran yang tidak memadai untuk melakukan sosialisasi. Media sosialisasi masih terbatas pada 
pertemuan secara langsung, karena masyarakat dan penerima $\mathrm{PKH}$ belum terbiasa mengakses media lain seperti media sosial dan media brosur lainnya. Sehingga imbasnya, Program PKH belum diketahui secara menyeluruh oleh semua stakeholders masyarakat Kecamatan Tabir Barat.

2. Kendala Teknis Dalam Proses Pendataan Penerima Program PKH

Dalam proses pendataan penerima untuk menentukan peserta penerima Program PKH di Kecamatan Tabir Barat mengalami berbagai kendala, diantaranya; data yang diambil dari Badan Pusat Statistik dipandang tidak mencerminkan keadaan masyarakat yang sebenarnya. Diindikasikan proses pendataan tidak dilakukan dengan prosedur yang benar, karena masih banyak masyarakat yang seharusnya menjadi peserta $\mathrm{PKH}$, tetapi tidak terdaftar. Selain itu, teridentifikasi bahwa penerima PKH kebanyakan dari keluarga perangkat desa dan kepala dusun, sehingga hal tersebut menimbulkan gejolak dan kecemburuan di masyarakat. Dari fenomena tersebut diperlukan pemutakhiran data, peserta yang menjadi penerima program PKH mendapatkan sesuai dengan target tujuan program PKH.

3. Kendala Teknis Dalam Pendampingan Program PKH

Kendala dalam proses pendampingan $\mathrm{PKH}$ oleh petugas kepada penerima $\mathrm{PKH}$, mengalami berbagai kendala teknis diantarnya; bahwa kendala dari petugas pendamping sendiri yaitu tidak selalu bisa hadir di lokasi pendampingan dikarenakan tempat tinggal pendamping jauh dari lokasi bertugas. Hal tersebut menyulitkan untuk selalu mendampingi peserta PKH di lapangan. Kemudian, kesulitan pendamping menuju akses wilayah pendampingan karena kondisi jalan yang masih berbatu dan jalan setapak, sehingga sulit untuk mengawasi kondisi penerima PKH.

Imbasnya dari kendala di atas dalam proses pendampingan oleh pendamping, tidak bisa memastikan perkembangan dari target tujuan program PKH berjalan dengan baik atau tidak dirasakan oleh peserta PKH. Selain itu, juga Pendamping kurang melakukan koordinasi dengan aparat setempat dan pemberi pelayanan pendidikan dan kesehatan. Kemudian, pertemuan bulanan dengan ketua kelompok dan seluruh peserta PKH juga tidak dilakukan. Petugas PKH otomatis ketika tidak melakukan pendampingan juga tidak memberikan motivasi kepada peserta PKH dalam menjalankan komitmennya. Padahal, dari proses pendampingan tersebut menjadi dasar dalam pemutakhiran data penerima atau peserta PKH selanjutnya, apakah ada kemajuan kesejateraan atau tidak.

Padahal Peraturan Menteri Sosial Nomor 1 Tahun 2018 tentang Program Keluarga Harapan Pasal 49 mengamanatkan Pendamping sosial bertugas:

a. memastikan Bantuan Sosial PKH diterima oleh Keluarga Penerima Manfaat PKH tepat jumlah dan tepat sasaran;

b. melaksanakan Pertemuan Peningkatan Kemampuan Keluarga bersama Keluarga Penerima Manfaat PKH paling sedikit 1 (satu) kali setiap bulan; dan

c. memfasilitasi Keluarga Penerima Manfaat PKH mendapatkan program bantuan komplementer di bidang kesehatan, 
pendidikan, subsidi energi, ekonomi, perumahan, dan pemenuhan kebutuhan dasar lain.

4. Kendala Teknis Dalam Penyaluran/Pendistribusian dan Penggunaan Dana Program PKH

Kendala teknis dalam proses pendistribusian dana PKH kepada RTSM yang dilakukan oleh Petugas PKH mengalami beberapa kendala, diantaranya yaitu: proses pendistribusian kadang terjadi keterlambatan waktu tidak sesuai jadwal saat pemberian dana kepada peserta $\mathrm{PKH}$, karena kendala sistem jaringan perbankan atau kantor pos setempat. Selain itu, kerap terjadi antrian yang padat saat pembagian dana dilakukan. Maka petugas akhirnya memilih kantor desa atau sekolah-sekolah terdekat yang terjangkau oleh RTSM sebagai tempat berkumpul untuk membagikan dana PKH.

Dalam hal penggunaan dana PKH oleh peserta PKH sering digunakan tidak sesuai ketentuan peruntukannya. Seharusnya dana PKH digunakan untuk kebutuhan pendidikan anak-anak sekolah dan kesehatan, tetapi sering digunakan untuk kebutuhan lain di luar ketentuan. Dana tersebut ada juga yang digunakan untuk memenuhi kebutuhan sehari-hari orang tua, jika mereka terdesak saat tidak bekerja.

Kendala yang dihadapi oleh peserta $\mathrm{PKH}$, dalam hal pendidikan misalnya masih banyak anak sekolah yang duduk di bangku SD dan SMP enggan bersekolah dengan alasan tempat sekolah terlalu jauh untuk diakses dan kemalasan anak serta tidak ada motivasi orang tua juga lingkungan membuat anak malas sekolah.

Adapun kendala yang dialami oleh peserta PKH dalam melakukan kegiatan perbaikan kesehatan. Diantaranya adalah masyarakat enggan ke tempat pelayanan kesehatan, karena tempat pelayanan dipandang terlalu jauh dan mengakibatkan operasional menjadi mahal, seperti ongkos transportasi dan akses jalan yang rusak. Kemudian kepercayaan masyarakat masih mengandalkan dukun anak dalam melakukan pengobatan kesehatan dan cara-cara tradisional baik pengobatan untuk balita maupun untuk mengurus ibu-ibu hamil, ketimbang petugas kesehatan yang disediakan pemerintah, seperti puskesmas. Persyaratan kesehatan yang sudah ditetapkan dalam protokol pelayanan kesehatan bagi peserta PKH belum dijalankan dengan baik. Seperti halnya kebiasaan yang dilakukan oleh beberapa penerima PKH dengan membeli obat warung jika anaknya sakit dan tidak membawanya ke Puskesmas yang sudah ditunjuk sebagai rujukan untuk pelayanan kesehatan.

\section{Upaya Pemerintah Desa Pulau Lebar Kecamatan Tabir Barat dalam mengatasi hambatan pada program PKH dalam Meningkatkan Kesejahteraan Masyarakat}

1. Meningkatkan Sosialisasi

Pemerintah Desa Pulau Lebar berupaya melakukan sosialisasi bagi masyarakat untuk mengikuti setiap kegiatan pendampingan agar program PKH berjalan sesuai dengan harapan yang telah ditentukan oleh pemerintah. Dalam kejelasan dan konsistensi tujuan ini adalah bagaimana peraturan program PKH memberikan petunjuk-petunjuk yang cermat. Kemudian, program disusun secara jelas skala prioritasnya, untuk dilaksanakan oleh para pejabat pelaksana PKH dan pihak lainnya dalam pelaksanaan Program PKH di Kecamatan Tabir 
Barat. Acuan dalam implementasi program PKH di Kecamtan Tabir Barat yaitu mengacu pada aturan pedoman umum PKH tahun 2017.

2. Pemutakhiran Data Penerima PKH

Pemerintah Desa Pulau Lebar berupaya melakukan pemutakhiran data penerima PKH bersama dengan pendamping $\mathrm{PKH}$ dan perangkat desa, kejelasan aturan dalam pemilihan peserta $\mathrm{PKH}$, dimana target penerima bantuan PKH adalah rumah tangga sangat miskin (RTSM). Hal ini dipandang tidak ada kekeliruan. Penetapan rumah tangga sebagai RTSM dilakukan dengan menggunakan metodologi dan indikator yang transparan (dengan melihat pedoman umum PKH tahun 2017). Buku pedoman tersebut menyajikan informasi lebih rinci mengenai: penentuan RTSM; pemilihan lokasi pelaksanaan ujicoba; dan pemilihan peserta PKH.

Proses selanjutnya adalah pemutakhiran data. Merupakan perubahan sebagian atau seluruh data awal yang tercatat pada Master Data Base. Beberapa contoh perubahan informasi dari rumah tangga seperti perubahan tempat tinggal, kelahiran anggota keluarga, penarikan anak-anak dari program (kematian, keluar/pindah sekolah, dan sebagainya). Kemudian, masuknya anak-anak baru ke sekolah, ibu hamil, perbaikan nama atau dokumen-dokumen lainnya.

Pemutakhiran data dilaporkan oleh peserta di UPPKH Kecamatan. Pendamping PKH bekerjasama dengan ketua kelompok ibu peserta PKH akan memverifikasi perubahan data terkait. Dari proses mekanisme pemutakhiran data $\mathrm{di}$ atas, teridentifikasi terjadi pelanggaran, karena banyak diantara warga yang memenuhi criteria RTSM tidak masuk menjadi peserta PKH. Kondisi tersebut sebenarnya sudah jelas mekanismenya tetapi tidak dijalankan dengan baik, sehingga konsistensi dengan tujuan PKH terhambat dan tidak terwujud.

Adanya aturan penetapan Inclusion dan Exclusion Error, hal tersebut sebagai upaya memenuhi jumlah quota peserta PKH untuk suatu wilayah tertentu karena adanya peserta yang tidak memenuhi persyaratan tetapi masuk sebagai preserta PKH dan sebaliknya ada peserta yang memenuhi persyaratan peserta PKH tetapi tidak menjadi peserta PKH maka dilakukan penggantian sesuai quota desa yang bersangkutan, dengan mekanisme. Dalam pelaksanaan PKH di Kecamatan Tabir Barat hal ini tidak terjadi, dimana aturan sudah menjelaskan secara rinci tetapi konsistensi dengan tujuan PKH tidak terwujud dengan baik. Karena ada beberapa mekanisme yang dilanggar oleh petugas atau pendamping $\mathrm{PKH}$.

Kejelasan aturan prosedur dalam pelaksanaan program PKH di Kecamatan Tabir Barat selanjutnya adalah dilakukan pertemuan awal, dimulai dengan pengiriman pemberitahuan terpilihnya RTSM sebagai peserta $\mathrm{PKH}$, yang disertai format perbaikan data RTSM, pernyataan persetujuan memenuhi ketentuan $\mathrm{PKH}$, dan undangan untuk menghadiri pertemuan awal oleh pihak Bank BRI. Pertemuan awal dikoordinasikan oleh UPPKH Kecamatan dengan mengundang petugas Puskesmas dan sekolah di kecamatan tersebut, hal ini berjalan sesuai prosedur.

3. Kepastian Jadwal Pembayaran

Selanjutnya prosedur pembayaran, dimana bantuan tunai hanya akan diberikan kepada RTSM yang telah terpilih sebagai peserta PKH dan mengikuti ketentuan yang diatur dalam program. Bukti 
kepesertaannya adalah kepemilikan kartu PKH yang tercantum nama ibu/wanita yang mengurus anak. Kartu PKH dikirim ke setiap peserta oleh pendamping sebelum pembayaran pertama dilakukan. Pembayaran bantuan dilakukan oleh PT Pos setiap tiga bulan pada tanggal yang ditentukan oleh masing-masing kantor pos untuk masingmasing desa/kelurahan.

Pembentukan kelompok ibu penerima bantuan. Setelah pembayaran pertama dilakukan, UPPKH Kecamatan memfasilitasi pertemuan kelompok ibu peserta PKH. Setiap 15-25 RTSM disarankan memiliki ketua kelompok yang berfungsi sebagai kontak bagi UPPKH untuk setiap kegiatan seperti antara lain sosialisasi, pelatihan, penyuluhan, penyelesaian masalah dan sebagainya selama program berlangsung. Ketua kelompok dipilih secara terbuka untuk menjaring kandidat yang secara sukarela memiliki komitmen tinggi untuk mensukseskan pelaksanaan PKH. Ketua kelompok terpilih tidak diperkenankan memungut bayaran apapun dari peserta $\mathrm{PKH}$, tetapi dapat mengikuti kegiatan seperti mengikuti sosialisasi, pelatihan, penyuluhan dan sebagainya yang dilaksanakan oleh program.

4. Penangguhan atau Pembatalan Peserta

Penangguhan dan pembatalan peserta PKH. Penangguhan sementara berlaku apabila peserta PKH tidak memenuhi komitmen yang telah ditentukan untuk 1 kali siklus pembayaran (3 bulan berturut-turut) dan peserta PKH tidak mengambil pembayaran untuk 1 kali siklus pembayaran ( 3 bulan berturut-turut). Kemudian untuk pembatalan dapat terjadi apabila RTSM terbukti tidak layak sebagai peserta $\mathrm{PKH}$, melalui antara lain pengaduan yang telah dibuktikan dan pengecekan berkala (spot check). Dalam 2 kali siklus pembayaran berturut-turut ( 6 bulan) RTSM tidak memenuhi komitmen tetapi melakukan klaim terhadap bantuan. RTSM yang telah dibatalkan kepesertaannya tidak dapat diajukan kembali sebagai penerima bantuan. Sejauh ini immpelemntasi program PKH di kecamatan belum ada yang dilakukan pembatalan

\section{Penutup}

Kesimpulan dari penelitian ini adalah program PKH efektif dalam meningkatkan kesejahteraan masyarakat Desa Pulau Lebar Kecamatan Tabir Barat, dimana PKH adalah membantu mengurangi kemiskinan dengan cara meningkatkan kualitas sumber daya manusia pada kelompok masyarakat sangat miskin. Dalam jangka pendek, bantuan ini membantu mengurangi beban pengeluaran RTSM, sedangkan untuk jangka panjang, dengan mensyaratkan keluarga penerima untuk menyekolahkan anaknya, melakukan imunisasi balita, memeriksakan kandungan bagi ibu hamil, dan perbaikan gizi, diharapkan akan memutus rantai kemiskinan antar generasi. Ada beberapa poin yang harus diperhatikan diantaranya: 1) Terdapat hambatan program PKH dalam meningkatkan kesejahteraan masyarakat Desa Pulau Lebar Kecamatan Tabir Barat, diantaranya adalah: rendahnya partisipasi masyarakat, kendala teknis dalam proses pendataan penerima program $\mathrm{PKH}$, kendala teknis dalam pendampingan program $\mathrm{PKH}$, serta kendala teknis dalam penyaluran/pendistribusian dan penggunaan dana program PKH. 2) Upaya Pemerintah Desa Pulau Lebar Kecamatan Tabir Barat dalam mengatasi hambatan pada program PKH dalam meningkatkan kesejahteraan masyarakat diantaranya; meningkatkan sosialisasi, pemutakhiran data penerima PKH, kepastian jadwal pembayaran, penangguhan atau pembatalan peserta. 
Selanjutnya, saran untuk penelitian selanjutnya adalah diharapkan partisipasi aktif dari pemerintah Desa Pulau Lebar dalam memberikan bimbingan bagi masyarakat penerima agar dapat menggunakan Dana PKH sesuai peruntukan yang telah ditentukan agar dapat membantu mengurangi kemiskinan ke depannya dan diharapkan pendamping PKH selalu mensosialisasikan program PKH terhadap seluruh masyarakat, tidak hanya penerima saja, agar masyarakat dapat membantu mengawasi program PKH agar berjalan sebagaimana mestinya.

\section{Referensi}

Adi, Isbandi Rukminto. (2019). Kesejahteraan Sosial (Pekerjaan Sosial, Pembangunan. Sosial, dan kajian Pembangunan), Depok: Rajawali Pers

BKKBN. (2002). Buku Sumber untuk Advokasi

Direktorat Jaminan Sosial, D. J. P. dan J. S., \& RI, K. S. (2012). Pedoman Umum Program Keluarga Harapan. Direktorat Jaminan Sosial. Direktorat Jaminan Sosial.

Halim, Abdul., (2004). Akuntansi Keuangan Daerah, Penerbit Salemba Empat.

Harbani Pasolong, (2007). Teori Administrasi Publik. : Alfabeta, Bandung,

Hari Lubis dan Martani Huseini. (2002). Pengantar Teori Organisasi: Suatu Pendekatan Makro. Jakarta: Departemen Ilmu Administrasi, FISIP UI.

Jurnal Administrasi Publik (JAP), Vol.2, No12, Hal. 1-6

Jurnal ISIP. Nomor 3 Tahun 2015, Vol. 2

Kajian Kebijakan Publik: Vol. 1 Nomor 1. (2016).

Kementrian Sosial RI. (2012). Pedoman Umum Program Keluarga Harapan. Direktorat Jaminan Sosial

Kuncoro, Mudrajad.(2004.)Otonomi Dan Pembangunan Daerah Reformasi, Pencanaan, Startegi, Dan Peluang. Jakarta: Erlangga.

Kurniawan, Agung. (2005). Transformasi Pelayanan Publik. Pembaharuan.

Lee, K. W., \& Hwang, M. (2016). Conditional cash transfer against child labor: Indonesia Program Keluarga Harapan. Asia Pacific Education Review, 17(3), 391-401.

Lidiana. (2014). Pengaruh dan Efektifitas Bantuan Program Keluarga Harapan (PKH) terhadap partisipasi pendidikan di Kecamatan Muara Tiga Kabupaten Pidie. Jurnal Ilmu Ekonomi, Volume 2,.

Mahmudi. (2005).Manajemen Kinerja Sektor Publik. UPP AMP YKPN, Yogyakarta,

Nainggolan, T., Sutaat, Sitepu, A., Padmi, T. A., Muchtar, Irmayani, \& Hutapea, B. (2012). PROGRAM KELUARGA HARAPAN DI INDONESIA: Dampak Pada Rumah Tangga Sangat Miskin di Tujuh Provinsi. Pusat Penelitian dan Pengembangan Kesejahterahan Sosial (P3KS).

Nuggroho, Riant. (2009). Public Policy. Jakarta: Kelompok Gramedia.

Peraturan Pemerintah (PP) Nomor 15 tahun 2010 tentang Percepatan Penanggulangan Kemiskinan

Soewarno Handayaningrat. (1994).Pengantar Studi Ilmu Administrasi dan Manajemen. Haji Masagung, Jakarta.

Suharto, Edi. (2011.) Kebijakan Sosial Sebagai Kebijakn Publik. Alpabeta: Bandung

Suleman, S. A., \& Resnawaty, R. (2017). Program Keluarga Harapan (PKH): Antara Perlindungan Sosial dan Pengentasan Kemiskinan. Prosiding Penelitian Dan Pengabdian Kepada Masyarakat, 4(1), 88-92.

Supriyono. (2000). Sistem Pengendalian Manajemen, Edisi Pertama, BPFE, Yogyakarta.

Undang-Undang Nomor 11 Tahun 2009 Tentang Kesejahteraan Sosial 